\title{
Who's Responsible? Issues in Eradicating Marine Litter In Aceh Jaya Regency
}

\author{
Ika Kusumawati ${ }^{1 *}$, Mita Setyowati ${ }^{2}$, Agung D. Syakti ${ }^{3}$, Achmad Fahrudin ${ }^{4}$, and Nodi Marefanda ${ }^{5}$ \\ ${ }^{1}$ Departement of Marine Science, Fisheries and Marine Science Faculty, Teuku Umar University, West Aceh Regency, Aceh \\ Province, Indonesia \\ ${ }^{2}$ Departement of agrotechnology, Agriculture Faculty, Teuku Umar University, West Aceh Regency, Aceh Province, Indonesia \\ ${ }^{3}$ Marine Science and Fishery Faculty, Raja Ali Haji Maritime University, Indonesia \\ ${ }^{4}$ Marine Science and Fishery Faculty, Bogor Agricultural Institute, Bogor, Indonesia \\ ${ }^{5}$ Department of State Administrations, Social and Political Sciences Faculty, Teuku Umar University, West Aceh Regency, Aceh \\ Province, Indonesia
}

\begin{abstract}
Marine debris is any persistent, manufactured or processed solid material discarded, disposed of or abandoned in the marine and coastal environment. Debris problem in coastal areas becomes an urgent issue and concerns many countries across the world particularly marine countries such as Indonesia. The research objective was to examine the people's perception towards marine litter in Aceh Jaya Regency about whom responsible for eradicating marine debris. The study was conducted from January to July 2019 by distributing a questionnaire to 382 respondents. The result showed that $46.9 \%$ of respondents thought that they were responsible for reducing marine litter. In a similar case, researchers found $53.4 \%$ of respondents stated that those who were able to reduce marine waste were community/visitors. The final finding is that $42.1 \%$ of the sample shows that NGOs are the parties who are eager to reduce marine litter.
\end{abstract}

Keywords: marine litter, responsible, and Aceh Jaya.

\section{Introduction}

Debris In the coastal area has become one of the complex problems faced by an area near the coast that has several rivers that flow into the ocean [1]. NOAA (2013) describes marine debris or marine litter as a persistent solid object, produced or processed by humans, directly or accidentally disposed of or left in the marine environment. Marine debris can originate from human activities on land that is directly or indirectly discharged into the ocean which can cause ecological damage in the ocean such as increased levels of acidity, coral bleaching, and other ecological damage at sea [2].

The marine debris consists of plastic, glass, metal, and rubber. $80 \%$ of the waste found in the oceans is plastic which is sourced from human activities on the coast and land [3]. [4] revealed that 322 million tons of plastic waste were dumped into the sea in 2015. Worldwide, plastic waste can be found in coastal areas, in the high seas and on the seafloor [5].

Plastics consist of synthetic or semi-synthetic polymerization products. This plastic is formed from organic condensation or addition of polymers and can also consist of other substances to improve performance or economy. There are several natural polymers including plastics. Plastics can be formed into films or synthetic fibers [6]. Plastic waste can damage the ecosystem and marine biota that eats decomposed plastic waste, and stores the substances that have been absorbed by the plastic pieces in the body of the marine biota.

The problem of marine debris is inseparable from the lack of role of the community in maintaining cleanliness, especially the culture of our people who are not aware of not littering and the low communication between stakeholders is also a problem related to the issue of marine debris [7]. Add to this the inadequate management and infrastructure in managing plastic waste and the lack of public knowledge about the impact of waste on their environment [8].

Marine debris is a broader problem related to waste management. Solid waste management has become a public health and environmental challenge which is very worrying in many countries such as Indonesia, where the existing waste management system, from source to final disposal or treatment, is inadequate [9].

There is a public perception that waste originates from 'other places', and that it is someone else who produces waste that is not my responsibility. At present, problems related to marine debris are compounded by problems from lack of awareness in the community about the problem of marine waste; lack of awareness of marine debris solutions; and lack of communication and mechanisms between different stakeholders. Therefore, based on the description above, it is very necessary to find

\footnotetext{
* Corresponding author: ikakusumawati@utu.ac.id
} 
out people's perceptions about who should be responsible for reducing marine debris.

\section{Materials and Methods}

\subsection{Research Location and Design}

The study was conducted in Aceh Jaya Regency, one of the districts in Aceh Province. Figure 1 shows a map of the Aceh Jaya Regency. The researcher uses a quantitative descriptive approach in this study to explain research problems that focus on the research objectives. This design is expected to be able to provide an overview of people's perceptions of who is responsible for reducing marine litter.

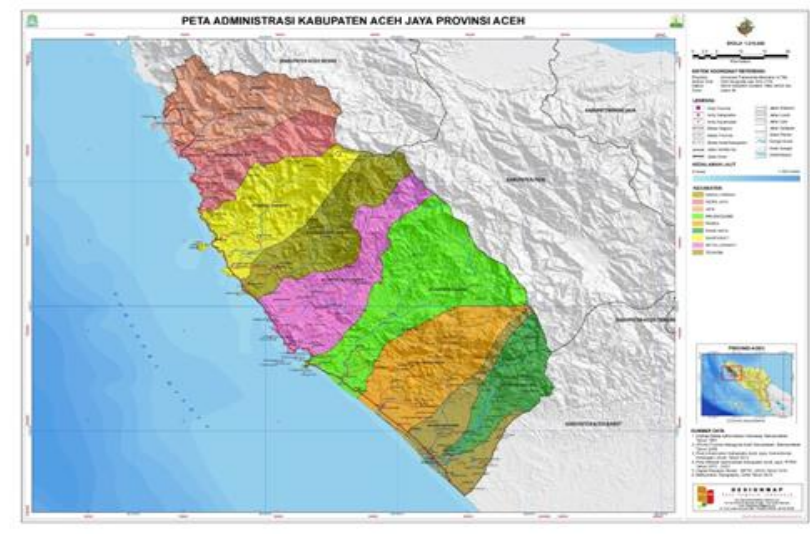

Source:https://petatematikindo.wordpress.com/2013/04/21/ad ministrasi-kabupaten-aceh-jayal

Figure 1. Map of Aceh Jaya Regency.

\subsection{Data collection}

Data was collected through a questionnaire survey from January to July 2019. The population size was 86,123 people [13], including residents of Aceh Jaya District. Samples were taken using purposive random sampling. The technique of determining the number of samples using http://www.surveysystem.com/sscalc.htm, with a confidence level of $95 \%$ and a confidence interval of 5. A total of 382 samples were selected in this study.

\subsection{Questionnaire Design and Data Analysis}

The questionnaire was designed in three stages. First, the initial questionnaire was prepared based on previous research. Second, the initial questionnaire was tested before by 50 respondents. The pre-test questionnaire was conducted face-to-face and received $95 \%$ responses. After revision by the respondent's pre-test, the final questionnaire was confirmed which was adapted from previous studies [7]. The questionnaire survey was conducted in private with closed questions. Responses will be analyzed through a statistical approach by providing basic information from descriptive data. Therefore, researchers will use SPSS 24 to run descriptive statistical data to obtain sufficient evidence from the perception of the community responsible for reducing marine litter/debris.

\section{Results and Discussion}

The study was conducted in the district of Aceh Jaya. Aceh Jaya has 9 sub-districts, where all sub-districts are in the coastal area. These nine districts are the main focus of questionnaire data collection to see the perception of the people of West Aceh Regency about who is responsible for reducing marine waste. From the results of data analysis, it shows that $46.9 \%$ of respondents think that they are responsible for reducing marine waste (Figure 2). 53.4\% of respondents stated that those who can reduce marine waste are community/visitors (Figure $3)$.

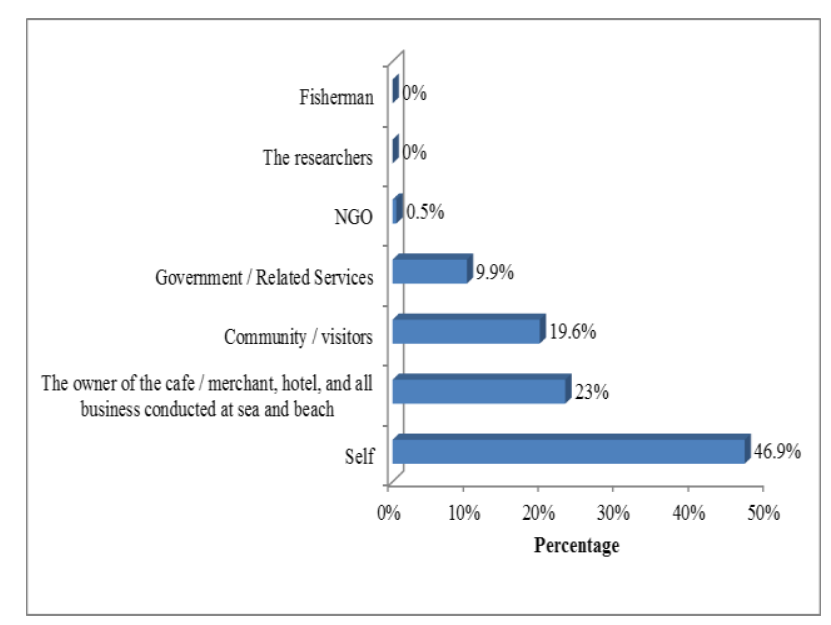

Figure 2. Responsible for reducing marine litter

Similarly, the ocean is polluted by debris because of human activities on the beach which abandon trash [10]. People's incompetence in managing debris becomes the core of the marine debris problem. Reducing marine waste starts with oneself, by changing human behavior towards the environment. Research conducted by [11] said that human behavior has the potential to make dramatic changes to the environment.

Start with yourself, then spread to the people around you to take part in protecting the marine environment. Handling plastic waste begins with ourselves. Some ways that can be done to reduce plastic waste produced in addition to some of the methods mentioned in the $3 \mathrm{R}$ activities above, namely bringing own drink bottles when traveling, bringing food containers if buying food to take home to replace plastic as a container, buying environmentally friendly plastic products. $42.1 \%$ of the sample shows that NGOs are those who want to reduce marine waste (Figure 4).

To reduce the amount of marine debris, changing the attitude is an important factor [12]. NGOs try to apply the full understanding of marine debris and human behavior is a requirement for successful management in order to eradicate marine debris from our ocean with clean up the ocean campaign. Changing bad behavior through education especially for young people is a vital step for raising the high awareness of marine litter 


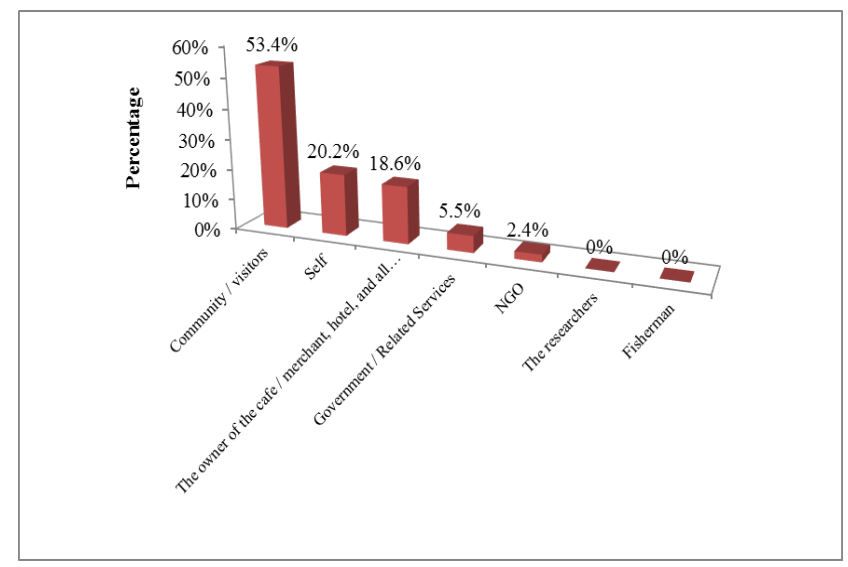

Figure 3. who are able to reduce marine litter

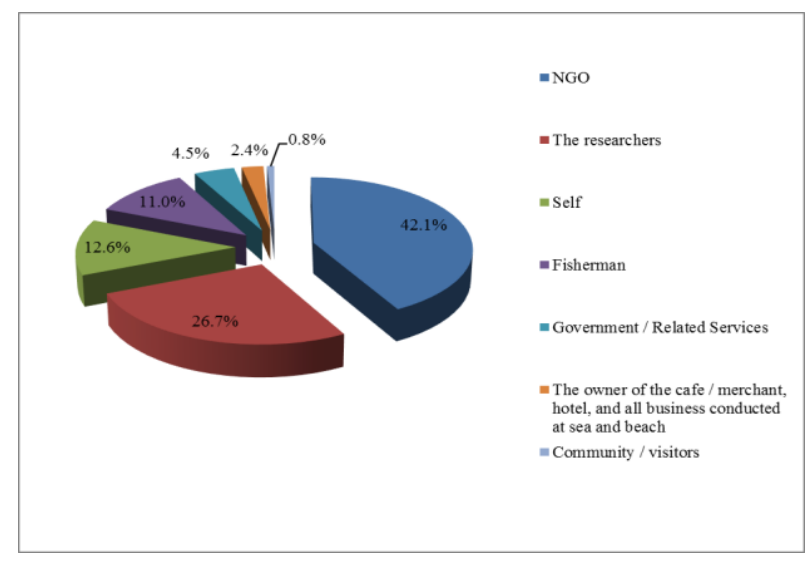

Figure 4. Stakeholders that are passionate in reducing marine litter

The low level of public awareness becomes an obstacle in reducing the amount of marine waste. Community behavior in disposing of waste, especially in developing countries, is one of the factors that make Indonesia the second-highest contributing marine waste in the world, followed by the Philippines, Vietnam and Sri Lanka [4]. Therefore, policies in terms of the coastal environment in Indonesia, especially in West Aceh District, are highly oriented in influencing community habits. Such policies are very useful in helping people who care about the dangers of waste to the marine ecosystem and are useful to motivate other communities to reduce marine waste [11]. Community behavior in disposing of garbage is strongly influenced by knowledge, attitudes, attention to environmental problems, and motivation to provide solutions [12].

\section{Conclusion}

The result showed that $46.9 \%$ of respondents thought that they were responsible for reducing marine litter. In a similar case, researchers found $53.4 \%$ of respondents stated that those who were able to reduce marine waste were community/visitors. The final finding is that $42.1 \%$ of the sample shows that NGOs are the parties who are eager to reduce marine litter.

\section{Acknowledgments}

We would like to thank Direktorat Riset dan Pengabdian Masyarakat (DRPM) from Kementerian Ristek Dikti for funding this research through the "skim hibah Penelitian Kerjasama antar Perguruan Tinggi”.

\section{References}

1. Dewi IS, Budiarsa AA, Ritonga IR : Distribusi mikroplastik pada sedimen di Muara Badak, Kabupaten Kutai Kartanegara. Jurnal Ilmu Perairan, Pesisir, dan Perikanan. Universitas Syiah Kuala. 2015; 4(3).

2. CBD (Convention on Biological Diversity) : Impacts of Marine Debris on Biodiversity. Current Status and Potential Pollution. CBD Technical Series. 2012;(67).

3. UNEP: The Global Garbage Crisis: No Time to Waste. 2012.

4. Jambeck RJ, Roland G, Chris W, et al. : Plastic Was Inputs From Land Into The Ocean. Journal Science. 2015;347(6223):768-71.

5. Gall SC, Thompson RC: The Impact of Debris on Marine Life. Marine Pollution Bulletin. 2015;92:170-9.

6. Leslie HA : Plastic in Cosmetics: Are we Polluting the Environment through our Personal Care: Plastic Ingredients that Contribute to Marine Microplastic Litter. UNEP; 2015.

7. Veiga JM, Vlachogianni T, Pahl S, et al.: Enhancing public awareness and promoting co-responsibility for marine litter in Europe: The challenge of MARLISCO. Marine Pollution Bulletin. 2016;102(2): 309-15.

8. Thevenon F, Carroll C, Sousa J : Plastic Debris in the Ocean: The Characterization of Marine Plastics and their Environmental Impacts, Situation Analysis Report, Switzerland: IUCN; 2014.

9. Schneider FW, Gruman JA, Coutts LM : Applied social psychology: understanding and addressing social and practical problems, Los Angeles: Sage; 2012.

10. Storrier KL, McGlashan DJ : Development and management of a coastal litter campaign: The voluntary coastal partnership approach. Marine Policy. 2006;30:189-96.

11. Leire C, Thidell $\AA$ : Product-related environmental information to guide consumer purchases-a review and analysis of research on perceptions, understanding and use among Nordic consumers. J. CleanerProd. http://dx.doi.org/10.1016/j.jclepro.2004.-12.004; 2005;13:1061-70.

12. Hartley BL, Thompson RC, Pahl S: Marine Litter Education Boosts Children Understanding and SelfReported Actions. Marine Pollution Bulletin. 2015;90: 209-17

13. Statistik Jumlah Penduduk. Tersedia dari http://bappedajakarta.go.id/?page_id=1131; 2015. 